\title{
VISI SEORANG HAMBA TUHAN
}

Pdt. Dra. $\mathcal{N}$ y. Nelly P. Tufumury, M.Div.

\section{PENDAHULUAN}

Ada orang berkata: "Orang Kristen yang paling rugi adalah orang Kristen yang hidup dan melayani tanpa Visi. Tetapi yang lebih rugi lagi ialah seorang pemimpin Kristen yang melayani tanpa memiliki Visi Ilahi yang jelas". Hal ini penting sekali, sebab seorang pemimpin Kristen yang melayani tanpa Visi yang jelas, akan banyak menghabiskan waktu dan energi tanpa hasil yang maksimal. Dan yang paling berbahaya, adalah sang pemimpin akan sangat merugikan semua yang dipimpinnya. Pelayanan dan kegiatan mereka tanpa tujuan, tanpa sasaran, tidak ada pencapaian maksimal, sebab tujuan dan sasaran yang jelas mengalir dari Visi yang jelas. Inspirasi dan kinerja yang konsisten memang mengalir dari Visi.

Pemimpin gereja yang tidak memiliki Visi yang jelas, bukan hanya tidak akan efektif dalam kerjanya, tetapi juga tidak mungkin menurunkan Visi yang jelas kepada Tim pemimpin Jemaat. Tim pemimpin Jemaat yang melayani tanpa arahan jelas dari Visi, tidak mungkin menurunkan Visi kepada anggota Jemaat. Ini menyebabkan setiap anggota jemaat hidup dan terlibat tanpa Visi pribadi. Joel Comiskey, menyatakan: "Seorang pemimpin yang memiliki Visi akan menyalakan api dan membuat sasaran ini makin hidup" (Joel Comiskey, 1998). Jadi sebaliknya, pemimpin yang tidak memiliki Visi, akan sangat sulit menggerakkan orang yang dipimpinnya ke arah pencapaian sasaran yang tepat. Inilah yang menjadi salah satu penyebab mendasar dari kelambanan, bahkan kegagalan banyak pemimpin Kristen, sehingga gereja lamban mengemban Amanat Agung secara efektif.
Itulah sebabnya, diskusi tentang pemahaman Visi seorang pemimpin Kristen adalah suatu kebutuhan mendesak yang akan memberkati tiap orang percaya terutama calon pemimpin sebelum lebih terlambat.

\section{PENGERTIAN VISI}

\section{Tinjauan Etimologis}

Kata Visi dalam bahasa Indonesia, berasal dari kata "vision" dalam bahasa Inggris. Dalam bahasa Ibrani, kata yang digunakan ialah "chazak", yang akar katanya berarti "to gaze at; mentally too perceive, contemplate (with pleasure); spec to have a vision of; behold, look, prophecy, provide, see" (Strong Exhorted Concordance). Dari pengertian itu, maka kata visi memiliki beberapa arti yaitu: memandang pada, memiliki roh atau jiwa untuk merasa, merenungkan, memiliki suatu penglihatan, memegang, melihat, menubuatkan, menyiapkan yang dilihat.

Dalam bahasa Yunani, kata yang digunakan adalah "harao" atau "raah", atau "optemai" yang berarti "to see", yang diartikan: "Vision as a supranatural presentation of certain scenary of sircumtances to the mind of a person while awake (Nahum 12:6-8). E.g. At the time of Eli. (is A. I Samuel 3:1; Prov. 29:18) (Strong Conc). Dari ungkapan etimologis di atas, disimpulkan bahwa: "Visi adalah pernyataan secara supra natural (dari Allah) yang disampaikan sebagai suatu skenario tertentu atau pada situasi tertentu ke dalam otak (hati) seseorang yang diterima secara sadar."

\section{Tinjauan Terminologis}

Beberapa ungkapan terminologis yang dapat diungkapkan tentang Visi 
berikut: dari latar belakang etimologis bahasa Ibrani, dapatlah disimpulkan bahwa "Visi ialah kemampuan roháni yang diberikan kepada seseorang untuk disampaikan sebagai nubuat, sesuatu yang dilihat akan terjadi di masa depan". Hal itu disampaikan sebagai persiapan dengan tujuan untuk dilakukan. Terminologi lain menyatakan bahwa "Visi adalah melihat ke depan", atau suatu kemampuan untuk melihat sesuatu yang paling akhir sejak permulaan (Yahya Iskandar, 1998). Ada juga yang mengatakan bahwa "Visi adalah suatu kemampuan yang diberikan dalam hati seseorang tentang sesuatu yang akan dilakukan dengan baik, dengan keyakinan bahwa ia sanggup melakukan hal itu secara tepat guna dan berhasil guna". Selanjutnya George Barna yang dikutip oleh Joel Comiskey, menyatakan bahwa "Visi adalah suatu gambaran yang ada di dalam pikiran Anda, tentang bagaimana seharusnya atau menjadi apa sesuatu pada hari-hari yang akan datang. Visi mengandung arti suatu realita visual, suatu potret kondisi, yang belum terjadi saat ini. Gambaran ini direnungkan dan bersifat pribadi". Visi itu juga sama dengan iman. Orang yang memiliki Visi Ilahi adalah orang yang beriman kepada Allah (J. Comiskey, 1998).

Selanjutnya John C. Maxwell, mengutip pandangan Robert K. Greenleaf dalam bukunya The Servant as Leader, ia berkata "Wawasan (kata lain untuk visi), adalah petunjuk yang dimiliki oleh pemimpin. Begitu dia kehilangan petunjuk ini dan peristiwa mulai memberikan tekanan, dia hanyalah pemimpin "dalam nama saja". Dia tidak memimpin, dia bereaksi terhadap peristiwa yang muncul seketika dan dia mungkin tidak akan lama menjadi pemimpin" (John Maxwell, 1995).

Dari semua data di atas, dapatlah disimpulkan bahwa "Visi adalah satu kemampuan yang diberikan kepada se- seorang tentang suatu tugas yang tergambar jelas dan termeterai dalam jiwanya, tentang apa yang seharusnya dicapai pada masa depan, dengan keyakinan bahwa orang itu mampu merealisasikan Visi yang dipercayakan padanya."

Dalam konteks bidang tugas seorang pemimpin Kristen, maka Visi itu adalah Visi Ilahi, dan dapat meliputi beberapa aspek sebagai berikut:

1. Seorang pemimpin Kristen ialah orang yang seharusnya memiliki hubungan yang hidup dengan Allah (Pemberi Visi).

2. Hubungan inilah yang memungkinkan Kristus memberikan tugas yang harus diembannya dan yang akan dibagikannya kepada orang yang dipimpinnya.

3. Tugas tersebut ditanam jelas dalam batinnya, sebagai tugas yang menjadi pedoman atau potret kerja sang pemimpin di masa depan.

4. Gambaran tugas ini akan semakin jelas dalam perenungannya secara batiniah.

5. Sang pemimpin yang menerima Visi adalah pribadi yang dilayakkan dan dianggap Kristus mampu merealisasikan Visi itu secara berhasil guna dan tepat guna.

Hanya dengan potret, alias pedoman kerja dalam Visi dan perenungan inilah, akan menjadi pemberi arah yang jelas bagi sang pemimpin dalam pelayanan yang memungkinkan dirinya menjadi pemimpin yang efektif "Pemimpin yang efektif merenungkan Visi mereka dan menjelaskannya kepada orang lain". (Comiskey, 1998).

\section{KEPENTINGAN VISI}

Salomo menulis "Bila tidak ada wahyu, menjadi liarlah rakyat. Berbahagialah orang yang berpegang pada 
hukum" (Amsal 29:18). Kata wahyu, diterjemahkan dengan "revelation". "A message from God, given through a prophet. A prophetic vision". (I Samuel 3:1; I Samuel 1:1; Amsal 8:11, 12) (The NIV Study Bible, 1985). Kata ini juga dijelaskan sebagai berikut "Where there is no vision, no prophet to expound the law, no priets or Levite to teach the knowledge of the Lord, no means of grace, the word of God was scarce, there is no open vision". (I Samuel 3:1), where it is so, the people parish. (Mathew Herry, in Mathew Henry's Commentary, 1960, p. 795). Jadi bila tidak ada Visi, tidak ada nabi yang menjelaskan hukum, tidak ada imam atau orang Lewi yang mengajarkan pengetahuan Allah, tidak ada makna anugerah, firman Allah tertutup dan tidak ada Visi yang terbuka, manusia menjadi akan liar sebab tidak ada Visi.

Lanjut penulis mengungkapkan pentingnya Visi yang disingkat sebagai berikut:

1. Betapa bahaya bagi manusia, bila di situ tidak ada pengertian dari Alkitab dan tidak ada para pelayan yang menjelaskannya, situasi itu memudah kan munculnya musuh jiwa.

2. Manusia jahat, bukan hanya menentang raja mereka, tetapi juga menentang Allah. Khotbah yang bagus membuat manusia mempunyai subjek yang bagus, tapi tanpa Visi akan siasia.

3. Manusia jadi bodoh dan main-main seperti anak-anak, bila gurunya tidak hadir bersama mereka.

4. Mereka akan tercerai berai, sebagai domba yang tak bergembala dan mereka membutuhkan pemimpin yang akan memanggil, mengumpulkan dan memelihara mereka bersama (Markus 6:34).

5. Mereka dihukum binasa, mereka dihancurkan oleh karena tidak adanya pengetahuan (Hosea 4:6). (Mathew Henry, 1960).
Dari kelima hal di atas, dapatlah disimpulkan betapa bahayanya, manusia bila tidak ada wahyu Allah yang akan menerangi dan mengarahkan mereka. Bila tidak ada pengajaran dari Alkitab, yang adalah firman Allah, tidak ada pedoman hidup bagi mereka. Mereka akan mati dalam kesalahan dan dosa mereka. Sebab hanya firman Allah yang dapat memperkenalkan Penebus bagi mereka (Yohanes 8:25). Hanya firman Allah yang dapat memperbaiki kehidupan manusia untuk berjalan menuju kesempurnaan (II Timotius 3:16).

Selanjutnya Salomo menjelaskan bahwa manusia hanya dapat mencapai kebahagiaan bila berpegang pada hukum. Yang dimaksudkan hukum di sini adalah hukum Allah atau firman Allah. Hal ini sesuai dengan apa yang dikatakan oleh raja Daud (Mazmur 1:1-6; 119:1-16). Dengan demikian, jelas bahwa Visi itu berasal dari Tuhan dan berdasarkan kebenaran firman Tuhan. Seorang pemimpin yang memahami betapa pentingnya manusia mengenal Allah dan firman-Nya, akan menyiapkan diri untuk melakukan apa yang akan Tuhan letakkan dalam batinnya, untuk dilakukan. Seorang pemimpin harus berdoa dan merenungkan firman Allah, memberikan waktu bagi Allah menyampaikan Visi yang harus diembannya, agar dapat menuntun manusia kepada pengenalan akan Allah berdasarkan firman Allah. Visi Allah bagi sang pemimpin Kristen harus bersumber dari firman Allah. Tanpa Visi, tujuan dan sasaran tidak jelas, dan tujuan yang tidak jelas mendatangkan hasil yang tidak jelas, akhirnya membawa kerja yang tidak efektif.

Jadi, benarlah ungkapan yang $m$ ngatakan bahwa "pentingnya Visi bagi orang Kristen ialah supaya hidupnya tidak sia-sia, tetapi tetap berada dalam pusat rencana Allah, bagaimana pun besarnya tantangan yang dihadapi" 
(Yahya Iskandar, 1998). Selanjutnya ada juga yang mengatakan bahwa "Pemimpin yang tidak memiliki Visi penjangakuan keluar, tidak mungkin membawa orang untuk menjangkau keluar. Pemimpin yang tidak mempunyai Visi pertumbuhan dengan firman, tidak mungkin mempengaruhi orang untuk bertumbuh dengan firman" (J. Cvomiskey, 1998).

Khusus dalam hubungan dengan menetapkan tujuan dan sasaran pelayanan ke depan, seorang pemimpin tidak mungkin melakukan hal ini tanpa Visi yang jelas. Tom Marshal, seorang dosen dan theolog serta pembicara yang dipakai Tuhan untuk memberkati banyak pemimpin di dunia, tetang kepemimpinan, menulis dalam bukunya Pemimpin yang Efektif, bahwa hal yang amat penting bagi seorang ialah mampu melihat ke masa depan, kepada apa yang terjadi di masa depan.

Tom Marshal mengutip pendapat Robert K. Greenleaf bahwa,

Suatu tanda bahwa mereka adalah pemimpin, suatu atribut yang menjadikan mereka dapat menunjukkan jalan kepada orang lain, adalah mereka lebih baik dari yang terbaik dalam menunjukkan arah yang harus dijalani. Tinjauan ke masa depan adalah "pimpinan" yang dimiliki oleh para pemimpin. Sekali para pemimpin kehilangan pimpinan ini, dan keadaan mulai menguasai mereka, kepemimpinan mereka pun tinggal nama belaka. (Tom Marshall, 1996).

Dari kutipan ini jelas bahwa kemampuan seorang pemimpin yang terpenting ialah mampu menentukan sasaran untuk masa depan. Selanjutnya dikatakan bahwa pemimpin yang mampu melihat ke masa depan hanyalah pemimpin yang memiliki Visi. Ini merupakan syarat pertama dari seseorang yang memiliki jabatan pemimpin. Bila tidak, maka ia akan gagal dalam kepemimpi- nannya. Tom Marshal menjelaskan bahwa yang mencakup kemampuan untuk melihat ke depan adalah: Pertama, tinjauan ke masa depan membutuhkan adanya Visi, dalam arti suatu wawasan yang berdaya angan atau "melihat" melalui mata batiniah. Visi lebih lazim dialami dalam bentuk ide atau konsep atau gagasan. Visi inilah yang memampukan pemimpin untuk "melihat" masa yang akan datang secara lebih jauh dan lebih jelas dari pada orang lain, mengidentifikasikan kesempatan dan kemungkinan secara lebih baik, dan mengerti bagaimana menanggapi peristiwaperistiwa yang akan terjadi atau situasisituasi serupa itu. Visi adalah tanda pokok semua pemimpin besar. Visi menjadi tanda bagi seorang Musa, seorang Yosua, seorang Samuel, seorang Daud atau pun seorang Nehemia (Tom Marshal, 1996).

Pernyataan Tom Marshall di atas, menjelaskan sekali lagi bahwa betapa pentingnya Visi bagi seorang pemimpin Kristen.

Kesimpulan dari semua analisis tadi, maka betapa pentingnya Visi bagi pemimpin secara praktis antara lain:

1. Visi memberi arah demi penetapan tujuan dan sasaran pelayanan ke depan. Tanpa Visi, tidak mungkin pemimpin dapat menetapkan sasaran ke depan. Tanpa Visi, dapat dikatakan bahwa pemimpin itu akan gagal dalam jabatannya sebagai pemimpin.

2. Visi membangun dan membakar semangat juang untuk tetap giat, mencapai tujuan.

3. Visi menguatkan komitmen untuk tekun dan ulet, bergerak dengan pasti menerobosi semua halangan bagaimana pun dahsyatnya.

4. Visi dari Allah, menolong membangun semangat ketergantungan kepada Tuhan dalam doa dan puasa karena kasih kepada Tuhan dan manusia yang terhilang. 
5. Pemimpin yang memiliki visi yang jelas, tekun berlari dengan Visi llahi dengan motto: "Rela mati demi tercapainya visi" (Bambang Budijanto, 1991).

\section{BEBERAPA CONTOH}

Dapat dikatakan semua orang yang dipakai Tuhan, baik dalam Alkitab maupun dalam sejarah gereja, umumnya memiliki Visi Ilahi yang jelas dari Allah yang memungkinkan mereka dapat mengemban tugas mereka secara berhasil guna dan berdaya guna, sehingga dapat dipanuti oleh semua yang melayani di era ini. Berikut ada beberapa tokoh dalam Perjanjian Lama (PL) dan Perjanjian Baru (PB), yang akan dikemukakan secara singkat.

\section{Perjanjian Lama}

Hanya ada beberapa contoh saja yang akan diangkat dalam para tokoh iman PL yang dapat diteladani oleh para pemimpin yaitu :

\section{Abraham}

Panggilan Allah kepada Abraham disertai Visi yang jelas. Dalam Kejadian 12:1-3, kita temukan bahwa Abraham pahami dengan jelas apa yang terkandung dalam panggilan Allah baginya. Pemahaman itu dibuktikan dalam ketaatan yang sungguh (Kejadian 12:4-6). Selanjutnya kita dapati Allah meneguhkan Visi yang diembannya dan Abraham meresponinya dengan penghormatan dan penyembahan (Kejadian 12:7-9). Selanjutnya dari teladan Abraham dapat kami singkatkan beberapa aspek:

a. Visi Allah dapat diterima seseorang sejak panggilannya atau pertobatannya.

b. Allah yang memberikan Visi, Allah memberikan kekuatan untuk mentaati Visi itu. c. Allah akan terus meneguhkan Visi yang telah diperlihatkan kepadanya dan menyertainya dengan perjanjian berkat (Kejadian 12:3).

d. Allah akan memelihara Visi itu dalam orang yang mentaatinya walau melewati tantangan yang berat (Kejadian 13:17; 17:2).

e. Allah meneguhkan perjanjian-Nya dan menguatkan dia untuk bertahan dan tetap beriman (18:10; Roma 4:1820).

f. Pemimpin yang siap mengemban Visi Ilahi, orang itu akan dipelihara dan dibimbing-Nya.

g. Allah menghargai orang yang taat melakukan Visi-Nya (Kejadian 22:1529; Roma 4:18-23).

\section{Yosua}

Dari kitab Yosua, kita temukan bahwa sepeninggal Musa, panggilan yang diberikan kepada Yosua untuk menggantikan tugas Musa, diberikan dengan Visi yang jelas yang menjadi misi Yosua untuk diembannya (Yosua 1:1-3). Tugas mengemban Visi itu juga disertai dengan janji berkat dan penyertaan-Nya dalam memimpin umat Allah memasuki tanah perjanjian (Yosua 1:2-9). Dapat dikatakan semua aspek yang disebutkan dalam hubungan Allah dengan Abraham sebagai orang yang mengemban Visi Ilahi sama dengan apa yang terjadi dalam pengalaman Yosua dengan Allah, walau tugas mereka berbeda.

\section{Nehemia}

Nehemia mengalami hal yang hampir mirip dengan yang dialami Yosua. Nehemia menerima Visi yang jelas dari Allah untuk pulang ke Yerusalem membangun kembali kota itu, (Nehemia 2:12). Walaupun kasus yang dihadapi Nehemia untuk diselesaikan berbeda dengan apa yang dihadapi oleh Abraham dan Yosua, namun prinsip dalam merealisasikan Visi itu sama. Yang dimaksud ialah Nehemiah 
bekerja berdasarkan Visi yang diberikan Tuhan dalam hatinya, untuk membangun kembali tembok Yerusalem walau ia harus menghadapi banyak kesulitan (Nehemia 1:1-11). Teladan khusus bagi setiap pemimpin untuk menerima Visi Ilahi adalah pergumulannya dalam doa dan puasa (Nehemia 1:4-11).

\section{Daniel}

Dalam Daniel pasal 1, khususnya ayat 8 kita temukan bahwa Daniel hadir di Babel walau lewat pembuangan, namun Daniel memiliki tekad kuat yang merupakan Visi bagi Daniel dan ketiga temannya untuk berdiri bagi Allah di tengah bangsa yang tidak percaya itu (band. Daniel 1:8). Semua janji yang diberikan Allah bagi Abraham dan Yosua tidak diulangi untuk Daniel dan Nehemia, namun mereka memiliki realisasi janji itu yaitu berkat dan penyertaan serta pemeliharaan Allah yang dahsyat dalam mengemban tugas masing-masing terutama dalam menghadapi pelbagai tantangan. Daniel dan ketiga temannya dipakai Allah untuk menyatakan kemuliaan dan kebesaran Allah di tengah bangsa yang tidak percaya. Mereka mampu bertahan dan menang, hanya oleh Anugerah Allah yang digerakkan oleh Visi yang Allah letakkan dalam hati mereka.

\section{Perjạjian Baru}

\section{Tuhan Yesus}

Tuhan Yesus yang adalah Allah sempurna dan manusia sempurna, patut menjadi teladan bagi kita terutama dalam merealisasikan Visi Allah dalam diri-Nya. Sebagai manusia sempurna, Tuhan Yesus memiliki Visi yang jelas, tatkala Ia berkata: "Makanan-Ku ialah melakukan kehendak Dia yang mengutus Aku dan menyelesaikan pekerjaan-Nya" (Yohanes 4:34). Hidup-Nya terpusat pada apa yang telah direncanakan Bapa bagi-Nya. Selanjut- nya waktu orang Yahudi mempesoalkan pelayanan-Nya, Yesus menyatakan bahwa apa yang dilakukan-Nya itu adalah sesuai dengan apa yang Bapa perlihatkan kepada-Nya. Kata Yesus: "Aku berkata kepadamu, sesungguhnya Anak tidak dapat mengerjakan sesuatu dari diri-Nya sendiri, jikalau tidak Ia melihat Bapa mengerjakannya: sebab apa yang dikerjakan Bapa, itu juga yang dikerjakan Anak" (Yohanes 5:19). Dari kebenaran ini di temukan teladan agung dari Juruselamat kita, di mana dalam pelayanan-Nya, Ia bekerja menurut apa yang dilihat dari apa yang dikerjakan Bapa-Nya. Inilah teladan misi, yaitu mengerjakan apa yang menjadi Visi bagiNya. Ia bekerja menurut rencana Allah bagi-Nya.

Bila dalam bekerja di ladang Allah, kita tidak jelas apa yang Allah berikan bagi kita sebagai Visi, maka kita juga akan tidak mungkin melaksanakan misi-Nya dengan benar. Ini akan dibicarakan dalam hubungan Visi dan misi kemudian.

\section{Rasul Paulus}

Apa yang menjadi tekad Paulus dalam pelayanan, dapat kita temukan dalam banyak tulisannya. Ia menulis: "Yang kukehendaki ialah mengenal Dia dan kuasa kebangkitan-Nya, di mana aku menjadi serupa dengan Dia dalam kematian-Nya" (Filipi 3:10). Ada orang yang menulis, bahwa setiap orang Kristen belum akan mencapai kualitas pelayanan yang memadai dan dapat dipakai oleh Tuhan sesuai kehendak-Nya, sebelum ia memiliki komitmen yang dimiliki oleh Paulus dalam ayat ini. Ayat ini merupakan salah satu kebenaran yang mendasari komitmen perjuangan Paulus yang begitu gigih dalam pekabaran Injil, yang diberikan Allah baginya. Tekad untuk mengembang Visi ini ditemui dalam banyak bagian kesaksian Paulus "Karena jika aku memberitakan Injil, aku tidak 
mempunyai alasan untuk memegahkan diri. Sebab itu adalah keharusan bagiku. Celakalah aku jika aku tidak memberitakan Injil" (I Korintus 9:16). "Tetapi waktu Ia, yang telah memilih aku sejak kandungan ibuku dan memanggil aku oleh kasih karunia-Nya, berkenan menyatakan Anak-Nya di dalam aku, supaya aku memberitakan Dia di antara bangsabangsa bukan Yahudi, maka sesaat pun aku tidak minta pertimbangan kepada manusia" (Galatia 1:15,16). "Karena bagiku hidup adalah Kristus, dan mati adalah keuntungan. Tetapi jika aku harus hidup di dunia ini, itu berarti bagiku bekerja memberi buah ..." (Filipi 1:21, 22). Inilah beberapa cuplikan komitmen Paulus dalam pelayanannya bagi kerajaan Allah. Misinya jelas digerakkan oleh Visi Ilahi yang dipercayakan kepadanya.

\section{KESAKSIAN GEREJA MASA KINI}

Berikut akan dikutip catatan Rich Warren, penulis Pertumbuhan Gereja Masa $K$ Kini yaitu gereja yang mempunyai Visi dan Tujuan. Rick Warren mencatat Visi Gerejanya sebagai berikut, (ini merupakan Ringkasan dari khotbah pertama Pdt. Rick Warren, 30 Maret 1980).

Visi gerejanya digambarkan sebagai berikut "Hasrat dari Tuhan":

Inilah hasrat akan suatu tempat di mana orang-orang yang sedih, yang depresi, yang frustrasi, dan yang bingung dapat temukan kasih, sambutan, pertolongan, harapan, pengampunan, bimbingan dan dorongan.

Inilah hasrat untuk berbagi kabar baik tentang Yesus Kristus kepada ratusan ribu penduduk di Orange County Selatan ini. Inilah hasrat untuk menyambut 20.000 anggota ke dalam persekutuan keluarga gereja kami yang saling mengasihi, saling belajar, saling bergurau dan hidup rukun bersama.

Inilah hasrat untuk berbuat orang bertumbuh sehingga mencapai kedewasaan rohani melalui Penelaahan Alkitab, kelompok kecil, seminar, retreat, dan sekolah Orientasi Melayani.

Inilah hasrat untuk melengkapi setiap orang percaya untuk pelayanan yang berarti, dengan menolong mereka menemukan karunia dan bakat yang sudah diberikan Tuhan kepada mereka.

Inilah hasrat untuk mengutus ratusan msionaris dan pekerja gereja ke seluruh dunia, dan memberi kuasa kepada setiap anggota agar mempunyai kehidupan pribadi yang misioner sampai ke seluruh dunia.

Inilah hasrat untuk mengutus ribuan anggota kami untuk melakukan misi jangka pendek ke setiap benua. Inilah hasrat untuk memulai paling sedikit paling sedikit sebuah gereja cabang setiap tahun. Inilah hasrat untuk memiliki paling sedikit 20 hektar tanah, di mana akan dibangun sebuah gereja setempat untuk Orange County Selatan, dengan fasilitas yang indah namun sederhana. Fasilitas ini termasuk pusat ibadah dengan tempat duduk untuk ribuan orang, ruang-ruang konseling ruang doa, ruang kelas untuk penelaahan Alkitab dan pelatihan untuk pekerja awam dan ruang rekreasi. Semua ini akan dirancang untuk melayani manusia seutuhnya (rohani, emosi, jasmani, dan sosial), semua ini akan ditata dalam taman yang indah dan tenang. Saya berdiri di depan saudara sekali, hari ini dan menyatakan dengan penuh keyakinan bahwa semua hasrat ini akan menjadi kenyataan. Mengapa? Karena hasrat ini diilhami oleh Tuhan. (Rick Warren, 1999, hal. 47).

Ketujuh hasrat ini menjadi Visinya sebagai pemimpin gereja, dengan banyak doa dan bergantung pada kekuatan Roh Kudus, semua yang diimaninya itu terlaksana hari ini dan menjadi kesaksian yang luar biasa dan Tuhan pasti dimuliakan serta banyak orang diselamatkan. 
Dengan demikian telah kita temukan baik contoh dan kesaksian para tokoh gereja sampai saat ini yang membukti bahwa seorang dapat digunakan oleh Tuhan secara luar biasa tergantung Visi yang diberikan Allah kepadanya.

Itulah sebabnya di bagian depan dikatakan bahwa hamba Tuhan yang tidak memiliki Visi bukan hanya merugikan diri dan kesaksian pelayanannya, tapi juga merusak para pengikutnya, sebab mereka tidak dapat menemukan apa yang Tuhan mau kerjakan melalui mereka bagi dunia ini.

\section{PRA-SYARAT BAGI PENERIMA VISI}

Belumlah lengkap bila tulisan ini bila tidak dikemukakan bagaimana cara seseorang dapat menerima Visi dari Allah yang akan menuntunnya kepada kehidupan yang berdaya guna serta pelayanan yang menyenangkan hati Tuhan. Beberapa saran berikut dari teladan tokoh Alkitab perlu dimiliki.

\section{Hubungan Pribadi dengan Allah}

Alkitab mendatakan semua orang yang memiliki Visi dari Allah adalah orang-orang yang dipakai Allah. Mereka adalah manusia Allah yang mempunyai hubungan pribadi yang akrab dengan Allah. Abraham misalnya sebelum dilantik sebagai Bapak orang beriman, ia telah memiliki hubungan yang baik dengan Allah. Hal mana terbukti dari ketaatannya dalam mendengarkan suara Allah tanpa berargumentasi (Kejadian 12:1-9). Allah tidak akan memakai orangorang yang tidak mengenal-Nya dan belum memiliki hubungan pribadi yang erat dengan Allah. Hanya orang mengenal Allah, akan memiliki hubungan pribadi yang intim dengan Allah melalui doa dan renungan Firman Tuhan tiap hari secara teratur (Band. Daud; Mazmur 5:4). Dengan terus mendengar suara Allah, Allah akan memberikan kemampuan untuk lebih mengenal Dia, kekuatan untuk mentaati-Nya dan akan semakin berkenan kepada-Nya dalam berbagai hal. Inilah yang diajarkan Paulus kepada semua orang percaya, tatkala ia menulis tentang pola hidup orang percaya dalam Kolose 1:9-112. Hal yang sama juga pada Nehemia, Daniel, Yosua dan semua hamba Tuhan lain baik dalam Alkitab maupun dalam sejarah gereja.

\section{Kesiapan untuk Mentaati Perintah Allah}

Para tokoh Alkitab baik dalam PL maupun PB yang diberikan Visi Ilahi, adalah mereka yang rela taat pada perintah Allah dan yang setia mendengarkan suara-Nya. Abraham mendengarkan semua yang difirmankan Tuhan, segera bertindak mentaati apa yang diperintahkan Tuhan kepadanya, walaupun perintah itu mengandung reziko tinggi dan berat baginya (Kejadian 22). Itulah sebabnya Allah menghargai ketaatan dan imannya itu dan mengaruniakan kepadanya status yang tinggi yaitu sebagai Bapak Orang beriman. Hal yang sama kita lihat dalam kehidupan Nuh, bagaimana ia mentaati Allah dalam mempersiapkan bahtera menjelang air bah (Kejadian 6-7). Sambil membuat bahtera, sambil memberitakan firman Tuhan, walaupun tidak ada satu orang pun yang mengahrgainya kecuali isteri dan ketiga anak dan isteri-isteri mereka. Nuh tetap taat dan dia diberkati Tuhan dan dihargai orang beriman dari segala abad dan tempat. Buah ketaatan adalah berkat, dan sebaliknya buah pelanggaran adalah kutukan (Band. Mazmur 1:1-6 \& Ulangan 28).

\section{Mengasihi Allah dan Jiwa yang Terhilang}

Kehidupan yang taat kepada Allah yang diperlihatkan oleh semua tokoh Alkitab adalah didasarkan atas kasih 
mereka kepada Allah. Baik Abraham, Nehemia, dan yang lainnya dalam PL maupun Yohanes, Paulus dll. dalam PB. Adalah orang-orang yang sungguh mengasihi Allah dalam hidup mereka. Demikian juga semua tokoh iman dalam sejarah gereja menyatakan hal yang sama.

Ada banyak lagi faktor yang dapat didatakan di sini, tapi dengan mencermati ketiga hal itu disertai ketekunan belajar dari kesaksian dan pengalaman para hamba Tuhan yang telah disebut di atas, tiap orang yang dapat memiliki disiplin rohani yang sama dengan yang telah mereka alami. Hal inilah yang memungkinkan mereka akan mendapat kepercayaan dari Allah dan Allah tidak segan memberitahukan Visi-Nya kepada mereka. Keadaan kekristenan, terutama kesaksian gereja dewasa ini, dalam upaya penginjilan amat perlu merenungkan baik kehidupan semua tokoh Alkitab khususnya belajar dan mengevaluasi diri dengan kesaksian kehidupan dan pelayanan Rick Warren yang telah dikemukakan di bagian depan.

\section{PENUTUP}

Orang yang amat rugi ialah mereka yang hidup tanpa atau di luar Visi Ilahi. Lebih dari itu, betapa malangnya pemimpin Kristen yang berjalan dan melayani tanpa Visi. Betapa ruginya Gereja atau persekutuan mitra gereja yang dipimpin oleh pemimpin tanpa Visi. Untuk itu, kiranya tulisan ini akan memberkati semua pihak yang membaca, dan dipakai oleh Roh Kudus untuk membuka pikiran kita, untuk menerima wawasan baru tentang Visi dari Tuhan. Tidak ada yang terlambat bagi mereka yang mau maju. Sekali lagi "Belum terlambat". Biarlah jangan Anda meninggalkan atau melepaskan tulisan ini sebelum Anda membuat Evaluasi diri secara jujur dan siap untuk berubah. Mohonlah belas kasihan Allah atas diri
Anda dan mulailah berdoa dengan tekun sampai Allah menyatakan isi hati-Nya yang akan menjadi Visi bagi Anda untuk diemban. Dengan demikian, Dia sendiri akan memberikan hikmat, kasih dan kemampuan untuk mengemban $V$ isi tersebut, sehingga banyak orang lain diberkati dan kerajaan Allah diluaskan serta nama Allah dimuliakan.

"Bagi Dialah, yang dapat melakukan jauh lebih banyak dari pada yang kita doakan atau pikirkan, seperti yang ternyata dari kuasa di dalam kita, bagi Dialah kemuliaan didalam Jemaat dan di dalam Kristus Yesus turun temurun dan sampai selama-lamanya Amin." (Efesus $3: 20-21$ ).

\section{Berkat Allah Adalah Pasti Bagi Setiap Rekan Kerja-Nya Yang Setia Tuhan Memberkati}

Salam dan Doa Penulis, April 2004

\section{DAFTAR PUSTAKA}

Barkar Kennoth, The NIV Bible Study, Zondervan Publishing House, G. Rapids Michiqm, 1984.

Comiskey Joel, Ledakan Kelompok Sel, Metanoia, Jogyakarta, 1999.

Dake Finis Jennings, Dake's Annotated Reforence Bible, Dake Bible Sales, Law Nemcerille, Georgid, 1981.

Douglas JD, (Organizing Editors): Nezo Bible Dictionery, IVP, Tyndale, House Publishors, Uheaton, Illonois, 1980.

Haggard Ted \& Jack Hayford; Cintailah Kotamu Bagi Kerajaan-Nya, $\mathrm{HPH}$, Jakarta, 1999.

Henry Mathew, Mathew Henry'C Commentary, Zondervan Pub. House, G. Rapid, Michiqm, 1979.

Iskandar Jahya, Tetap Mekar di Masa Sukar, Patmos, 1998.

James Strong, Exhautive Concordance of The Bible, Verginia, Mc. Donald Publishing Companny.

Jones Laurie Beth, Yesus: Chief Executive Manager, Mitra Utama, Jakarta 1997. 